\title{
İç Tehditler ve Dış Politika: Gürcistan Dış Politikası Örneği (1991-2003) \\ ***
}

\section{Internal Threats and Foreign Policy: Georgian Foreign Policy Case (1991-2003)}

\author{
Selim DURSUN \\ Sakarya Üniversitesi, Sosyal Bilimler Enstitüsü, Doktora Adayı \\ Özet
}

Bu makale iç tehditlerin dış politika davranışına etkisi üzerinedir. Makale temel olarak devletlerin yüzleştiği iç tehditlerin onların dış politika davranışını etkilediğini iddia etmektedir. Literatürde, iç tehditlerin dış politikaya etkisi genellikle rejim güvenliğine yönelik tehditler açısından incelenmektedir. Bu makale rejim güvenliğine yönelik iç tehditlerin yanı sıra, toprak bütünlüğüne yönelik iç tehditleri de dikkate almaktadır. $\mathrm{Bu}$ tehditler devletlerin dış politikada sistemik güç dağılımına uygun davranmaktan alıkoyabilmektedir. Bu öngörüler 1991-2003 dönemi Gürcistan dış politikası örnek olayıyla da doğrulanmıştır. Gürcistan dış politikası bu dönemde büyük ölçüde iç tehditlerin ölümcül etkisi tarafından belirlenmiştir.

Anahtar Kelimeler: İç Tehditler, Rejim Güvenliği, Ayrılıkçı Hareketler, Dış Politika, Gürcistan.

\section{JEL Sinıflandırması: Z00}

\begin{abstract}
This article is about the impact of domestic threats on foreign policy behavior. Essentially, the article claims that the internal threats faced by the states affect their foreign policy behavior. In the literature, the impact of domestic threats on foreign policy is generally examined in terms of threats to regime security. This article considers domestic threats to regime security as well as internal threats to state territorial integrity. These threats can be prevented by acting in accordance with the systemic distribution of power in the foreign policies of the countries. This prediction was also confirmed by the case of Georgia foreign policy in the period 1991-2003. The foreign policy of Georgia was largely determined by the deadly effect of domestic threats in this period.
\end{abstract}


Keywords: Internal Threats, Regime Security, Separatist Movements, Foreign Policy, Georgia.

JEL Classification: Z00

\section{GÍRIŞ}

Dış politika davranışları üzerinde yaygın realist literatür devletlerin genelde yükselen dış tehdide veya güce karşı önlem aldıkları üzerinedir. Ancak yine realist paradigma içindeki bazı çalışmalar iç tehditlerin de devletlerin dış politika davranışlarını belirlediğini ortaya koymuştur. Bu yaklaşımlara göre iç tehditler, sistemik güç dağılımında olduğu gibi liderleri veya dış politika yapıcılarını sınırlandırmakta ve dolayısıyla dış politika davranışlarını etkilemektedir. Liderler ülke veya rejim güvenliğini tehlikeye atan ve bu nedenle birincil derecede tehdit oluşturan iç tehditlere karşı dış politika stratejisi geliştirirler. Bu strateji iç tehditlere karşı dış destek alma şeklinde gerçekleşeceği gibi, iç tehditlere yoğunlaşabilmek için dış tehditleri yatıştırmak şeklinde de olabilmektedir.

Literatürde iç tehdit kavramsallaştırması, genellikle rejim güvenliğine yönelik olarak sınırlandırılmaktadır. Ancak rejim güvenliğini tehdit etmeyen ancak devletin hayatta kalmasını tehlikeye atan toprak bütünlüğüne yönelik tehditler de devletlerin dış politika davranışlarını belirleyebilmektedir. Hatta devlet liderleri rejime yönelik iç tehditlerle birlikte ayrılıkçı hareketlerden kaynaklanan toprak bütünlüğüne yönelik iç tehditlerle de yüzleşebilirler. Ayrıca liderler toprak bütünlüğüne yönelik iç tehditlerin üstesinden gelemediklerinde, rejim güvenliğine yönelik tehditlerle de karşılaşabilirler. $\mathrm{Bu}$ durumda rejim güvenliğine yönelik tehditler diğer iç tehditlerin sonucu olmaktadır. $\mathrm{Bu}$ nedenle toprak bütünlüğüne yönelik tehditler rejim güvenliğine yönelik tehditlere göre daha yaşamsal olabilmektedir.

$\mathrm{Bu}$ makalede iç tehditlerin dış politikaya etkisini kavrayan teoriler kullanılmakla birlikte, iç tehdit tanımı toprak bütünlüğüne yönelik tehditleri de kapsayacak şekilde genişletilmiştir. Ayrıca makalede iç tehditlerin varlığının yanında iç tehdit düzeyi de devletlerin dış politikalarını ve bu politikalarındaki değişimleri belirlediği savunulmaktadır. İç tehdit düzeyi 
tehdidin yoğunluğuna, sayısına ve mücadeledeki başarıya göre düşük, yüksek ve çok yüksek olabilmektedir.

Makalenin birinci bölümünde iç tehditlerin dış politikayı nedensel olarak nasıl belirlediğine ve bu tehditlerin nasıl tanımlandığına yönelik literatürdeki tartışmalara değinilmektedir. İkinci ve üçüncü bölümde birinci bölümden elde edilen teorik ve kavramsal çıktıların sınanması için detaylı örnek olay incelemesi yapılmaktadır. Örnek olay olarak 1991-2003 dönemi Gürcistan dış politikası seçilmiştir. Bu örnek olayın seçilmesinin nedeni, hem toprak bütünlügüne hem de rejim güvenliğine yönelik iç tehditlerle yüzleşen Gürcistan'ın dış politikası üzerinde söz konusu tehditlerin nedensel etkisinin olup olmadığını gösterebilmektir.

\section{2. İÇ TEHDİTLER VE DIŞ POLITIKKA}

Uluslararası ve dış politikada devletlerin davranışlarını açıklamaya yönelik geleneksel yapısalcı realist yaklaşım, anarşik yapıda devletler, arasındaki güç dağılımını dikkate alır. Bu yaklaşıma göre, devletler güç dağılımındaki konumlarına göre davranır ve sistemdeki yükselen güce veya tehdide karşı stratejiler geliştirirler ${ }^{1}$. Yine realist paradigma içinde bazı çalışmalar iç tehditlerin de devletlerin dış politika davranışlarını belirlediğini ortaya koymuştur. Bu yaklaşıma göre iç tehditler, sistemik güç dağılımının etkisine benzer biçimde, liderleri veya dış politika yapıcılarını sınırlandırmakta ve dış politika kararlarını etkilemektedir. İç tehditler devlet ve rejim güvenliğini tehlikeye attıklarından devletler bu tehditleri birincil tehdit olarak tanımlarlar ve bu tehditleri dengelemeye yönelik dış politika stratejisi geliştirirler. Bu strateji iç tehditlere karşı dış destek alma şeklinde

\footnotetext{
${ }^{1}$ Bu yaklaşımların bir kısmı için bkz. Kenneth N. Waltz, Uluslararası Politika Teorisi, Çev. Osman S. Binatl1, Phoenix, 2010; Kenneth N. Waltz, "Uluslararası Politikanın Değişen Yapısı", Uluslararası Illişkiler, Cilt 5, Say1 17, 2008, s.3-44; Stephen M. Walt, "Alliances in a Unipolar World," World Politics, Cilt 61, No.1, 2009, s. 86-120; Stephen M. Walt, "Testing Theories of Alliance Formation: The Case of Southwest Asia", International Organisation, Cilt 42, No.2, s.275-316; Randall L. Schweller, "Bandwagoning for Profit: Bringing the Revisionist State Back In", International Security, Cilt 19, No.1, 1994, s.72-107; Michael Handel, Weak States in the International System, Londra, Frank Cass, 1990; William C. Wohlforth, "Revisiting Balance of Power Theory in Central Eurasia", T. V. Paul et.al. (ed.), Balance of Power; Theory and Practice in the 21st Century, Stanford, Stanford University Press, 2004, s. 214-238.
} 
ortaya çıkabileceği gibi, iç tehditlere yoğunlaşabilmek için dış tehditleri yatıştırma şeklinde de ortaya çıkabilir.

İç tehditlerin bazı devletlerin (Üçüncü Dünya devletleri, küçük veya zayıf devletler) dış politika davranışlarının en önemli nedeni olduğunu savunan birçok yaklaşım bulunmaktadır. Steven R. David'in (1991) her şeyi dengeleme teorisine göre, Üçüncü Dünya devletlerin ittifak davranışları liderlerin ve rejimlerin yüzleştiği iç tehditler ve bu tehditlerden kaynaklanan hayatta kalma sorunları görmezden gelinerek açıklanamaz. Üçüncü Dünya liderleri ikincil düşmanları yatıştırarak, iktidarda ve hayatta kalmak için birincil iç ve dış tehditlerin her ikisine karşı dengeleme yaparlar. David dış politika davranışı olan ittifakların en güçlü belirleyeninin Üçüncü Dünya liderlerinin hayatta kalmasının yönlendirdiğini söyler. Çünkü bu devletlerde liderlerin iktidarına ve hayatta kalmasına yönelik iç tehditler diğer devletlerden gelen tehditlerden daha çoktur. Liderler de anlaş1lır şekilde en yakın ve birincil olan tehditlere karşı koymak amacıyla daha az tehdit doğuran diğer devletleri yatıştırırlar. Bu sayede iç rakiplerinin uluslararası ittifaklarını yatıştırmış olurlar ve enerjilerini en tehlikeli iç rakiplerine odaklama imkânı bulurlar. $\mathrm{Bu}$ davranış görünüşte ikincil tehdit oluşturan devlet ya da devletlerin peşinden gitme gibi görünür, ancak bu en önemli ve yakın düşmanla savaşmak için gücünü koruma ve düşmanı dengeleme politikasıdır (s. 235-239). Michael N. Barnett ve Jack S. Levy (1991), Üçüncü Dünya ülkelerinin ittifak davranışlarını iç istikrar ve ekonomi politik tercihleri dikkate alan bir yaklaşımla açıkladılar. Onlara göre güvenlik sağlamada dış ittifak kurma ile dengeleme ve iç kaynaklarla dengeleme arasında bir değiştokuş vardır. İç tehditlerin varlı̆̆ 1 ve materyal kaynakları iç tehditlere karş1 kullanma gereksinimi nedeniyle liderler dış ittifaka yönelerek dış kaynak desteği sağlayabilirler. Dış tehdit ortaya çıktığı zaman yetersiz iç kaynakların dış tehditlere karşı kullanılması durumunda ise toplum refahı azalacağından toplumsal huzursuzlukların ortaya çıkmasına sebep olabilir. Bu nedenle liderler rejime yönelen iç tehditlere karşı kullanılabilecek kaynakları güvenceye alabilmek ve israf etmemek için dış ittifak arayışına girebilirler (s. 369-376). Richard J. Harknett ve Jeffrey A. Vandenberg (1997) de benzer şekilde, devletlerin ittifak davranışlarının dış tehditlerden ziyade iç tehditler 
tarafından yönlendirildiğini ileri sürdüler. Onlara göre bir devlet rejimine yönelen yakın bir iç tehdidi dengelemek için uzun bir süre tehdit oluşturan bir dış güçle ittifak yapabilir. Onlara göre bu durumda ittifakların temel belirleyeni bir rejime karşı tehdidin yoğunluğudur. Belirli koşullarda bir liderin bireysel hayatta kalma endişesi bile dış ittifak davranışını motive edebilir. Liderler bazen uzun dönem devlet çıkarları pahasına kendilerini korumaya çalışırlar. Bu açıklamalar güvenlik ittifaklarının belirli bir rejimin yüzleştiği en yakın ve önemli tehdide bir tepkinin sonucu olduğu varsayımına dayanmaktadır. Devletler en yakın ve birincil olabilen bu iç tehditleri dengelemek için veya onu yatıştırmak için uluslararası ittifak arayışına girebilirler. Çoğu Üçüncü Dünya ve Sovyet Birliği’nin yıkılmasından sonra ortaya çıkan devletlerde iç tehditlerden kaynaklanan ittifak davranışları görülebilmektedir.

İç tehditler devletleri belirli bir dış politika davranışına zorladığı gibi, aynı zamanda dış tehditleri dengeleme çabalarında etkinliği zayıflatabilir. Randall L. Schweller (2004) bu durumu yetersiz dengeleme kavramiyla açıklar. Ona göre sosyal bölünme, hükümet veya rejim kırılganlığı, elit bölünmüşlüğü ve tehdide nasıl cevap verileceği konusunda elit uyuşmazlığı gibi iç uyumsuzlukla yüzleşen devletler bir dış tehdide muhatap olduklarında o tehdidi yeterli bir şekilde dengeleyemezler. Örneğin rejim kırılganlığı sorunu ile muhatap olan devletlerdeki liderler diğer devletlerdeki liderlere göre, tehdidi dengelemek için iç kaynaklardan faydalanma imkânı noktasında daha çok sınırlandırılmıştır. Meşruiyet bakımından zayıf liderler diğer liderlere göre daha az siyasi kapasiteye sahip olurlar. Zayıf meşruiyet iç kaynakları bitirebilir. Rejim, muhalifleri yatıştırma, onları kendi saflarına kazanma veya hayatta kalma çabası içine girebilir. Bu durum kıt ulusal kaynakların tükenmesine yol açabilir. Ancak dış ittifak, bir tehdidi dengelemede göreceli olarak daha az maliyet yükler. $\mathrm{Bu}$ nedenle zayıf rejimlerin tehdide karşı koymak için savunma harcaması yapmak yerine, dış ittifak arayışı içine girmeleri daha muhtemeldir.

$\mathrm{Bu}$ yaklaşımlarda iç tehditler rejim güvenliği açısından tanımlanmaktadır. Bu tehditler rejim güvenliğini tehlikeye atmakta ve rejimi devlet-toplum ilişkileri bakımından kırılgan hale getirmektedir. Dolayısıyla 
rejime veya hükümetin hayatta kalmasına yönelik tehditlerin yoğunluğu rejim kırılganlığ1 olgusunu ortaya çıkartır. Schweller'e göre (2004), rejim kırılganlığ mevcut yönetim ya da liderliğin iktidardan uzaklaşma ihtimalinin yükssekliğine işaret eder. Bu kavram yönetenler ile yönetilenler arasındaki ilişkiyi kavramaya çalışır. Bu ilişki rejimin otoritesinin zorlamaya ya da halkın meşruiyetine dayanabilir. Ancak rejim güvenliğini tehdit etmeyen ancak devletin hayatta kalmasını tehlikeye atan toprak bütünlüğune yönelik tehditler de devletlerin dış politika davranışlarını belirleyebilmektedir. Ayrıca rejime yönelik iç tehditlerle birlikte ayrılıkçı hareketlerden kaynaklanan toprak bütünlüğüne yönelik iç tehditlerle birlikte ortaya çıkabilmektedir. Bunun yanında yönetici elitler toprak bütünlüğüne yönelik iç tehditlerin üstesinden gelemediği durumlarda rejim güvenliğine yönelik tehditlerle de karşılaşabilirler. $\mathrm{Bu}$ durumda rejim güvenliğine yönelik tehditler diğer iç tehditlerin sonucu olmaktadır. $\mathrm{Bu}$ nedenle toprak bütünlüğüne yönelik tehditlerin var olduğu durumlarda, bu tehdit hükümet veya rejim açısından birincil ve en hayati tehdit olarak ortaya çıkabilmektedir. Bu nedenle iç tehdit tanımının toprak bütünlüğüne yönelik tehditleri de kapsayacak şekilde genişletilmesi, tanımın daha kapsayıcı olmasını sağlayacaktır. Çeşitli nedenlerle ortaya çıkan toprak bütünlüğüne yönelik tehditler de devletlerin dış politika davranışlarını belirleyebilmektedir. Bu tehditlerle yüzleşen liderler bu tehdide gücünü odaklayabilmek için dış ittifak arayışına girebilirler. $\mathrm{Bu}$ ittifaklar dış kaynak sağlama, ayrılıkçı hareketlerin dış ittifaklarını yatıştırma veya ayrılıkçı iç tehditlere yönelik sert önlemlere yönelik dış tepkileri yumuşatma amacına yönelik olabilmektedir.

Devletlerin yüzleştiği ve onların dış politika davranışlarını yönlendiren iç tehditlerin birçok nedeni bulunmaktadır. Özellikle Üçüncü Dünya devletlerinin ve Soğuk Savaş sonrasında ortaya çıkan devletlerin çoğunda iç tehditler genellikle onların yapısal özelliklerinden kaynaklanmaktadır. $\mathrm{Bu}$ özellikler onları güçlü devletlerden farklı olarak zayıf ve küçük devlet kategorisine sokmaktadır. Richard Jackson'a göre (2002), güçlü devletler toplum üzerinde kontrole sahip olabilen, yasalarla sosyal uyumu sağlayabilen, iç istikrarı koruyabilen, politikalarını uygulamaya geçirebilen, temel hizmetleri gerçekleştirebilen, ulusal ekonomiyi kontrol edebilen ve 
meşruiyetini koruyabilen devletlerdir. Jackson zayıf devletleri ise güçlü devletlerden farklı olan iç karakteristik özelliklerle tanımlar. Ona göre zayıf devletleri güçlü devletlerden ayıran birkaç özellik vardır. Bu özellikler arasında demokrasi ve meşruiyet eksikliği, uyumlu ulusal kimliklerin yokluğu, yetersiz kurumsal kapasite ve kaynaklar bulunmaktadır. Mohammed Ayoob da (1984) zayıf ya da Üçüncü Dünya devlet yapılarının diğer devlet yapılarından farklı olduğunu savunur. Ona göre bu devletlerin rejimleri önemli oranda iç tehditle yüzleşirler. Dış tehditler iç tehditlere göre oldukça düşüktür ve genellikle iç tehditlerle birleşerek bu tehditleri artırırlar. Üçüncü Dünya devletlerinin çoğunda meşruiyet sorunları olduğundan, bu devletlerin çoğunun sınırlı ve dar bir toplumsal desteğe sahip rejimler tarafindan yönetilmesine yol açmaktadır. $\mathrm{Bu}$ rejimler kendi güvenliklerini devlet güvenliği olarak tanımlarlar. Çünkü rejimin devamına yönelik en büyük tehdit toplumun içinden gelmektedir. Dar bir elit çevresi ile temsil edilen rejimler yönetimde kalabilmek için topluma baskı kurarlar ve eşitsiz ekonomiler yaratırlar. Bu baskı ve eşitsizlikler onların güvenliğine ve devlet yapılarına yönelik iç tehditleri daha da artırmaktadır (s. 43-46).

David de benzer şekilde (1991), Üçüncü Dünya devletlerin yüzleştiği iç tehditlerin en önemli nedeni olarak bu devletlerin karakteristik yapılarını gösterir. Ona göre, bu devletlerin büyük çoğunluğu dış güçler tarafindan yapay olarak inşa edilmiş ve sınırları çizilmiştir. Bu nedenle bu devletlerde iç uyum ortaya çımamıştır. Başka bir deyişle bu yapaylık, ulusaltı gurupların ulusal çıkarlardan ziyade kendi çıkarları adına davranma ve bu guruplara bağlılığa mecbur olma durumunu ortaya çıkarmıştır. Bireyler devlet ile tanımlanan kimlik yerine etnik, dini veya bölgesel guruplara göre kimliklerini tanımlamışlardır. $\mathrm{Bu}$ şekilde tanımlanan çıkar tipleri ulusal bir bilincin oluşmasını engellemiştir. Devlet de farklı guruplar arasındaki farklılıkları aşmaktan ziyade merkezde iktidarı elinde tutan bir gurubu temsil eder duruma gelmiştir. Bu nedenle meşruiyet Üçüncü Dünya devletlerinde zayıftır. Bu durumdaki liderler zor kullanarak iktidara gelirler ve iktidarda kalmak için baskı yöntemlerini kullanırlar. Meşruiyet eksikliği yüzünden onlar daima iç tehditlerle yüzleşirler. 
Ayrıca iç tehditlerin varlığının yanında, iç tehdit düzeyi de devletlerin dış politikalarını ve bu politikalarındaki değişimleri belirler. İç tehdit düzeyi tehdidin yoğunluğuna, sayısına ve mücadeledeki başarıya göre düşük, yüksek ve çok yüksek olarak sınıflandırılabilir. İç tehditlerin dengelendiği, yatıştırıldığı, bir kısmının ortadan kaldırıldığ 1 , dış desteğinin azaltıldığ 1 durumlarda düşük düzeyde iç tehditten söz edebiliriz. Yeni iç tehditlerin ortaya çıkması, bu tehditleri dengelemede devletin kendini yeterli görmesi ve çatışmalara varan sert önlemler alması yüksek tehdit düzeyine işarettir. Ancak tehditlerin dengelenmesi konusunda başarısızlık, iç tehditlerin çok boyutlu hale gelmesi ve uluslararasılaşması gibi durumlar iç tehditlerin çok yüksek olduğunu gösterir. Genelde devletlerin dış politika değişimleri çok yüksek iç tehdit düzeyinde gerçekleşir.

Devlet ya da rejim güvenliğine yönelik iç tehditler çeşitli görünümler alabilmektedir. Rejim güvenliğine yönelik iç tehditlerin büyük çoğunluğu darbeler yoluyla ortaya çıkmaktadır. David'e göre (1991) Üçüncü Dünya devletlerinin çok azı dış işgale maruz kalmıştır. Ancak, bu devlet liderlerinin yüzlercesi onların iç düşmanları tarafindan devrilmiştir. Bu devletlerdeki rejim değişikliklerinin çoğu darbeler yoluyla gerçekleşmektedir ve bu şekilde yaklaşık 200 rejim değişikliği meydana gelmiştir. Jackson, zayıf devletlerin sahip olduğu yapısal özelliklerin zora dayalı uyum, hükümet krizleri, darbeler, ayaklanmalar ve isyanlar gibi istikrarsızlıklar ürettiğini savunur.

Miller ve Toritsyn'e göre (2005), liderliğin iktidarını ve hatta hayatta kalmasını tehlikeye atan suikast girişimleri, darbeler, iç savaşlar gibi iç tehditlerin bu tipleri Üçüncü Dünya ülkelerinin yanında Bağımsız Devletler Topluluğu (BDT) ülkelerinde de sık sık ortaya çıkmıştır. İç tehditlerle yüzleşen bu liderler çok daha fazla bu tehditlere odaklanmak zorunda kalmışlardır. Bu odaklanma BDT ülkeleri bağlamında Rusya gibi dış tehdit olarak görülebilecek devletlerle ittifak yapmalarına yol açmıştır. Miller ve Toritsyn, iç tehdit kavramsallaştırmasını genişletirler. Onlar liderliğin hayatta kalmasını tehlikeye atan ateşli muhalefet liderini veya partiyi de iç tehdit kavramı içine alırlar. Bu ülkelerde ateşli muhalefet hareketi ile karşılaşan liderler anayasaya veya kurallara aykırı bir şekilde rejim değişikliğinden 
endişelenirler. Nitekim Gürcistan, Ukrayna ve Kırgızistan'da bu şekilde ortaya çıkan devrimler liderleri iktidardan etmiştir.

Toprak bütünlüğüne yönelik iç tehditler rejim güvenliğine yönelik iç tehditlerden farklı olarak ayrılıkçı hareketler şeklinde ortaya çıkmaktadır. Ayrılıkçı hareketler genellikle özerklik, bağımsızlık, komşu ülkelerin topraklarıyla birleşme gibi taleplerle ortaya çıkabilmektedirler. Bu hareketler yöntem olarak silahlı mücadele içine girebilmektedirler. Bu nedenle toprak bütünlügüne yönelik iç tehditler, büyük oranda merkezi yönetimle ayrılıkçı harekeler arasındaki silahlı çatışmalar şeklinde görünüm almaktadır.

\section{GÜRCISTAN'IN YÜZLEŞTİĞİ İÇ TEHDITTLER}

Sovyetler Birliği’nin dağılması sürecinde 1991 yılında bağımsılılı̆ını kazanan Gürcistan, bağımsızlıktan sonra birçok iç tehditle yüzleşti. Bu tehditlerin en önemlisi toprak bütünlügüne yönelik ayr1lıkçı hareketlerden kaynaklandı. Gürcistan'a bağlı özerk birimler olan Abhazya ve Güney Osetya, Sovyetler Birliği'nin dağılması ve Gürcistan'ın bağımsızlığı sürecinde ayrılıkçı bir çaba içine girdiler. Gürcistan'ın bu çabalara karşı sert tutumu iç çatışmalara ve savaşlara neden oldu. Çatışma ve savaş ortamı ülkenin iç istikrarına ve toprak bütünlügüne büyük zarar verdi. Gürcistan'ın yüzleştiği ikinci iç tehdit rejim güvenliğine yönelik eylemlerden kaynaklandı. Gürcistan'da meydana gelen iktidar değişikliklerinin çoğu anayasal usullere uygun olarak gerçekleşmedi. İktidar değişiklikleri darbeler, isyanlar, halk ayaklanmaları gibi normal olamayan yöntemler sonucunda gerçekleşti. Gürcistan'ın bağımsızlık sonrasında yüzleştiği bu iç tehditler, Gürcistan'ın dış politika yapımını belirleyen bir ağırlık taşıdı.

\subsection{Toprak Bütünlüğüne Yönelik Tehditler}

Gürcistan bağımsılılıtan sonra toprak bütünlüğüne yönelik ayrılıkçı hareketlerden kaynaklanan iç tehditlerle yüzleşti. Sovyetler Birliği hâkimiyeti döneminde Gürcistan içinde birçok etnik ve dinsel özerk yapılar oluşturulmuştu. Bu özerk yapıların en önemlileri olan Abhazya ve Güney Osetya, Gürcistan'ın bağımsızlığı sürecinde alternatif ve etnik milliyetçiliğe dayalı ayrılıkçı ulusal projeler benimsedi (Nodia, 2005: 44-45). Rusya sınırları 
içindeki Kuzey Kafkasya halklarına yakın akraba olan Abhazlar ve Osetler², kendilerini Gürcistan ulusal projesinin dışında gördüler. Onların bu konudaki yaklaşımları bu durumu açıkça ortaya koymaktadır: "Biz Gürcü değiliz. Biz yalnızca işgal edilmiş topraklardaki kadim bir halkız. Gürcüleri de içeren diğer gruplar bu topraklarda yaşayan misafirlerdir. Bizim yaşadığımız topraklar Gürcü toprağı değildir ve Gürcistan'dan ayrılmalıdır. Kuzey Kafkasya'daki topluluklarla birleşmek en büyük arzumuzdur" (Nodia, 2005: 50-51). Gürcüler ise topraklarını tarihi Gürcü anavatanı olarak kabul ederler. Etnik gruplar arasındaki bu yaklaşım farklılıkları Gürcistan'ın bağımsızlık ve devlet yaratma sürecinde şiddetli çatışmalar üretti. Çatışmalar sonucunda Abhazya ve Güney Osetya, 1990'lı yılların başlarında yarı bağımsızlık elde etmeyi başardı. Bu gelişmelerin sonucunda ayrılıkçı bölgelerde yaşayan halk, Gürcistan ulusal kimliğinden ayrı topluluklara dönüştü ve yeniden entegrasyon ihtimali oldukça zayıfladı (Nodia, 2005: 50-51).

Gürcistan'ın en büyük ayrılıkçı bölgesi olan Abhazya'daki sorunun temeli Sovyetler Birliği’nin ilk y1llarına kadar gider. 1917 Bolşevik devrimi sonrasında Gürcistan Ulusal Konseyi ile Abhazya Halk Konseyi arasında 9 Şubat 1918 tarihinde imzalanan anlaşmayla Abhazya'nın sınırları belirlendi. Anlaşmada, Abhazya'nın siyasi geleceğinin halkların kendi kaderini belirleme hakkı ilkesine göre belirleneceği ifadesi de yer aldı. Ancak Gürcistan 26 Mayıs 1918'de Abhazya'nın merkezini ele geçirerek bölgeye hâkim olmaya başladı. İki taraf arasında yaşanan gerginliklerden sonra Gürcistan yönetimi Abhazya'ya özerklik statüsü verdi. Abhazlar da 20 Mart 1919 tarihinde Abhazya'nın Gürcistan içinde özerkliğini kabul etti (Oğan, 2011: 197-198). 1921 yılında Bolşevik ordusunun Gürcistan'1 işgal etmesinden sonra 31 Mart 1921'de Abhazya Sovyet Sosyalist Cumhuriyeti ilan edildi ve 21 Aralık 1921 tarihinde Abhazya, Gürcistan Sovyet Sosyalist Cumhuriyeti ile birlik anlaşması imzalayarak Gürcistan'a katıldı. Ancak 1931 yılında Abhazya'nın anlaşmalı cumhuriyet statüsü kaldırılarak yapısı özerk cumhuriyete dönüştürüldü (Ağacan, 2011: 83). Özellikle anlaşmalı cumhuriyet statüsünün kaldırılması Abhazya ile Gürcistan arasındaki

\footnotetext{
${ }^{2}$ Osetlerin büyük çoğunluğu Rusya'da özerk birim olan Kuzey Osetya Özerk Cumhuriyeti’nde yaşar. Abhazlar da diğer Kuzey Kafkasya halklarına yakındır (Nodia, 2005: 50-51).
} 
güvensizliği artırdı. Özerklik statüsü konusunda iki taraf arasındaki gerilim, Sovyetler Birliği'nin yıkılmasıyla gün yüzüne çıktı.

Gürcistan'ın Sovyetler Birliği'nin dağılması sürecinde bağımsızlık yönünde karar almasından sonra, Abhazya yönetimi de Gürcistan'dan ayrılmaya yönelik karar aldı. Abhazya, 25 Ağustos 1990'da devlet egemenliği ile ilgili kendi kaderini tayin hakkına atıf yapan bir deklarasyonu kabul ederek Abhazya'nın egemen bir cumhuriyet olduğunu ilan etti. Yine Abhazya Gürcistan'1n Şubat 1992'de yaptığı anayasa değişikliğine karşıt olarak 23 Temmuz 1992 tarihinde mevcut Abhazya anayasasını yürürlükten kaldırarak özerklik öncesi 1925 anayasasına dönme kararı aldı. Bu karar Gürcistan tarafından Abhazya'nın bağımsızlık ilanı olarak görüldü. Abhazya'nın bağımsızlık yönündeki kararından sonra Ağustos 1992'de Gürcistan silahlı birlikleri Abhazya'ya girdi. Yaklaşık bir yıl süren savaşta Abhazlar Gürcü taarruzunu durdurarak Gürcistan'1 askeri olarak yenilgiye uğrattı (Ağacan, 2011: 84; Oğan, 2011: 202-203). 30 Eylül 1993 tarihinde biten savaş sonrasında sorunun çözümüne yönelik BM, AGİT ve Rusya arabuluculuğunda "Gürcistan-Abhazya Anlaşmazlığının Barışçıl Çözümü İçin Öneriler Deklarasyonu" imzalandı. Taraflar ateşkese uymayı, birbirlerine karşı kuvvet kullanmamayı ve bölgeye barış gücünün yerleştirilmesini kabul etmeyi taahhüt ettiler. Bu anlaşma kapsamında tamamı Rus askerlerinden oluşan 1800 kişilik BDT barış gücü bölgeye yerleştirildi. Bu süreç sonunda Abhazya fiilen bağımsız bir duruma geldi. 26 Kasım 1994 tarihinde Abhazya Anayasa's1 kabul edilerek 1994, 1999 ve 2004 yıllarında başkanlık seçimleri yapıldı (Oğan, 2011: 204-205). İlerleyen y1llarda sorunun çözümü ve toprak bütünlüğünün sağlanmasına yönelik Gürcistan'ın çabaları sonuç vermedi.

İki taraf arasında savaşa neden olan Abhazya sorunu, Gürcistan'ın bu dönemde yüzleştiği iç tehdit düzeyini oldukça yükseltmiştir. Gürcistan savaşta yenilene kadar iç tehditlerle kendi imkânlarıyla dengeleme politikası izlemiştir. Abhazya'ya karşı savaşın kaybedilmesi, başka bir deyişle iç dengeleme stratejisinde başarısız olunmasından sonra, Gürcistan dış politikasını değiştirerek dış dengeleme arayışına girmiştir. Bu kapsamda Gürcistan daha önce tehdit olarak gördüğü Rusya ile işbirliği arayışı içine girmiştir. 
Gürcistan'ın toprak bütünlüğünü tehdit eden ve dış politikasını etkileyen diğer sorun Güney Osetya problemidir. Osetler Abhazlar'dan farklı olarak hem Rusya'da hem Gürcistan'da yaşayan bir halktır. Bolşevik devrimi sonrasında Osetya'nın güney bölgesi 1918 yılında Gürcistan'ın egemenliği altına girerken, kuzey bölgesi Kuzey Osetya adıyla Bolşevik Rusya egemenliği altında kaldı. Gürcistan'daki Osetler, Rusların desteğiyle Gürcistan içinde özerk bölge statüsü elde ettiler. Ancak Gürcüler, Güney Osetya bölgesini Gürcistan'ın tarihsel bir parçası olarak görürler ve Osetlerin kuzeyden göç ettiklerini iddia ederler. Buna karşın Osetler ise yaşadıkları toprakların kendi ana vatanları olduğunu savunurlar (Kantarc1, 2011: 239241). Bu yaklaşım farklılıkları iki taraf arasındaki problemin temelini oluşturmuştur.

Sovyetler Birliği'nin dağılma sürecinde Osetler, kuzey ve güney olarak ikiye bölünmüşlüğü ortadan kaldırarak tek bir çatı altında toplanma amacını yani birleşik Osetya projesini temel hedef haline getirdiler. Gürcistan'ın Sovyetler Birliği'nden ayrılma çabalarına paralel olarak Osetler de, Gürcistan'dan ayrılarak kuzeydeki Osetlerle birleşmek için Rusya'ya katılma taleplerini ifade etmeye başladılar. 10 Kasım 1989'da Güney Osetya yönetimi, Gürcistan'dan özerk bölgeden özerk cumhuriyet statüsüne geçilmesi talebinde bulundu ve kendisini Güney Osetya Cumhuriyeti'ne dönüştürdü. Ayrica yönetim, Gürcistan'dan ayrılarak Sovyetler Birliği'ne katılmayı kararlaştırdı. Gürcistan ise bu karara anayasa değişikliği ile Güney Osetya'nın özerk bölge kaldırarak karşılık verdi. Ardından Gürcistan, 6 Ocak 1991 tarihinde Güney Osetya'da düzeni sağlamak gerekçesiyle askeri faaliyet başlattı. Bu ortamda Ocak 1992'de Güney Osetya'da yapılan referandumda, yüzde 90 oranındaki çoğunluk Gürcistan'dan ayrılarak Rusya'ya katılma yönünde karar verdi. Bu karar sonrasında artan çatışmalar 24 Haziran 1992 tarihinde ateşkes ilan edilene kadar devam etti. Soruna Rusya'nın müdahil olmasıyla Rusya ve Gürcistan arasında, Haziran 1992'de sorunun çözümü için bir anlaşma imzalandı. Bu anlaşma ile çatışma bölgesinde Rus, Gürcü ve Osetlerden oluşan bir barış gücünün yerleştirilmesi kabul edildi. Bu kapsamda Temmuz 1992'de 700 Rus, 469 Oset ve 320 Gürcü askerinden oluşan barış gücü bölgede görev yapmaya başladı (Kantarc1, 2011: 254; Ağacan, 2011: 81-82). 
Bu dönemden 2003 yılına kadar geçen süreçte Güney Osetya sorununda önemli bir gelişme yaşanmadı. Gürcistan, 1990'lı yılların başlarında kaldırdığı Güney Osetya'nın özerklik statüsünü geri vermeme politikasını sorunun çözümünü engellemesine rağmen devam ettirmiştir. Bu politikaya uygun olarak, 1995 yılında kabul edilen yeni Gürcistan Anayasası'nda da Güney Osetya'nın özerklik statüsüne yer verilmedi. Gürcistan, Osetlerin özerk statüye sahip olmaları için hiçbir tarihi dayanaklarının olmadığını, eski Gürcü yurdu olan bu bölgeye özerkliğin Sovyet yönetimi tarafından keyfi gerekçelerle verildiğini savunmaktadır. İki taraf arasındaki yaklaşım farklı1ıkları, Haziran 1992'deki ateşkesten sonra bölgede barış gücünün görev yapmaya başlaması ve sorunun çözümsüz kalması gibi nedenler Güney Osetya'yı bu süreç sonunda fiili bağımsız bir birim haline getirmiştir. Güney Osetya' da bağımsız bir birim olarak davranmaya başlamıştır. Bu kapsamda 10 Kasım 1996 tarihinde Güney Osetya'da cumhurbaşkanlığı ve parlamento seçimleri yapılmıştır. Nisan 2001 'de de anayasal değişiklikler için referandum yapılmış ve değişiklikler yürürlüğe konulmuştur. Gürcistan ise bu girişimlere karşı çıkmış ve referandumu geçersiz kabul etmiştir. Bu süreçte sorunun çözümü için Rusya'nın girişimleri olduysa da çözüme yönelik bir sonuç alınamamıştır (Kantarc1, 2011: 258-260). Güney Osetya sorunu da Abhazya sorunu gibi bağımsızlıktan hemen sonra Gürcistan'ın istikrarına ve toprak bütünlüğüne zarar vererek iç tehdit düzeyini yükseltmiştir. Bu sorun yaklaşık altı ay süren çatışmalardan sonra 24 Haziran 1992 tarihinde imzalanan ateşkes anlaşmasına kadar Gürcistan açısından yüksek tehdit düzeyinde kalmıştır. Ateşkes anlaşmasından sonra bölgeye yerleştirilen Rusya öncülügündeki barış gücü sorunun dondurulmasına yol açmıştır. Ateşkes anlaşması ve sorunun dondurulmasıyla Güney Osetya'dan kaynaklanan iç tehdit düzeyini düşüren Gürcistan gücünü Abhazya sorununun çözümüne yönlendirmiştir.

\subsection{Rejim Güvenliğine Yönelik Tehditler}

Gürcistan'ın iç istikrarına yönelik iç tehditlerden rejim güvenliğine yönelen tehditler toprak bütünlüğüne yönelen tehditlere göre ikincil derecede kalmıştır. Bağımsızlıktan itibaren Gürcistan'daki iktidar değişimleri genelde normal şekilde gerçekleşmemiş şiddetli halk gösterileri, darbeler ve devrimler 
gibi olağanüstü yollarla gerçekleşmiştir. Ayrıca özerk siyasal hareketler de bazı dönemlerde rejim güvenliğini tehdit edecek seviyeye gelmiştir.

Rejim güvenliğine yönelik tehditlerin birincisi özerk siyasal hareketlerden kaynaklanmıştır. Bu hareketlerden en önemlisi, Acara Özerk Cumhuriyeti başkanı Aslan Abaşidze'nin 1991-2004 arası dönemde merkezi hükümetle yaşadığı siyasal problemlerdir. Acara Özerk Cumhuriyeti, Gürcistan'ın Acara bölgesinde yaşayan Gürcü Müslümanların dini haklarını korumak için 1921'de oluşturuldu ve 1921 Kars Anlaşması'yla onayland. Bağımsızlıktan sonra Gürcistan ile Acara arasındaki sorun etnik, dini veya ayrılıkçı olmaktan ziyade siyasal bir sorundu. Abaşidze özerk yapıyı kullanarak kişisel bir yönetim sistemi oluşturdu. Abaşidze kurduğu bu sistemle özel ordu kurma, merkezi hükümete vergi gelirlerini ödememe, Batum limanı ve gümrük kapılarında merkezi hükümetin kontrolünü engelleme gibi eylemler içine girdi. Abaşidze'nin merkezi hükümete başkaldırması ile aynı ülke içinde iki farklı siyasi rejimin bir arada var olmasına yol açtı. Abaşidze'nin başında olduğu siyasal parti ülke genelinde yüzde 20 çoğunluğa ulaşarak dönemin Gürcistan başkanı Şevardnadze ile ülke yönetimi için koalisyon kurma aşamasına geldi. Abaşidze'nin merkezi yönetim üzerinde artan etkisi, Acaristan benzeri kişisel yönetim rejiminin tüm ülkede egemen olacağı korkusuna yol açtı. Bu durum 2003 yılında Gürcistan başkanı Şevardnadze'nin istifasına yönelik şiddetli protesto hareketlerinin sebeplerinden birisi oldu (Nodia, 2005: 53-55).

Bağımsızlıktan sonra Gürcistan'da rejim güvenliğine yönelik tehditlerin ikincisi, gücün normal yollardan transfer edilmesindeki başarısızlıktı. Gamsahurdiya ve Şevardnadze iktidarlarını normal şekilde devretmekten ziyade darbeler ve halk ayaklanmalarıyla iktidarı birakmaya zorlandı (Nodia, 2005: 66). Zviad Gamsahurdiya 26 Mayıs 1991 tarihinde yapılan devlet başkanlığı seçimini kazanarak Gürcistan'ın ilk devlet başkanı oldu. Ancak Gamsahurdiya'nın iktidarı uzun sürmedi. Birkaç ay sonra Gamsahurdiya'nın devlet başkanlığından istifa etmesi ve erken genel seçimler yapılması talebiyle muhalefet parti liderlerinin öncülüğünde gösteriler başladı. Bu sırada Gamsahurdiya yönetiminde yer alan başbakan Tengiz Sugua, Gamsahurdiya'ya bağlı askeri birlik olan Ulusal Muhafizlar Komutanı 
Tengiz Kitovani ve diğer askeri birlikler muhalefet cephesine geçti. Bu gelişmeler üzerine Gamsahurdiya 6 Ocak 1992 tarihinde başkent Tiflis’i terk etmek zorunda kaldı. Gamsahurdiya'nın Tiflis'i terk etmek zorunda bırakılmasıyla yönetime el koyan ulusal muhafızların komutanı Tengiz Kitovani, süvarilerin komutanı Jaba İoseliani ve eski başbakan Tengiz Sugua'dan oluşan Askeri Konsey, Sovyetler Birliği’nin eski dışişleri bakanı Eduard Şevardnadze'yi Devlet Konseyi'nin başına geçmeye davet etti. Şevardnadze 7 Mart 1992 tarihinde daveti kabul ederek Devlet Konseyi'nin başına geçti (Ağacan, 2011: 62-63). Muhalefet partisi öncülügünde başlayan halk gösterileri sırasında askeri unsurların devreye girmesiyle hükümet darbesiyle iktidar değişikliği gerçekleşmiş oldu.

Şevardnadze'ye karşı iktidar mücadelesini kaybeden Gamsahurdiya taraftarlarıly birlikte Megrelya bölgesine çekilerek bölgenin kontrolünü ele geçirdi. Ağustos 1993'te Gürcistan'ın Abhazya'ya yenilmesi sonrasında Gamsahurdiya taraftarları Tiflis'e doğru harekete geçti (Ağacan, 2011: 6465). Zviadistler olarak adlandırılan bu güçler Abhaz savaşı sırasında Megrelya'da hükümet güçlerine sürpriz saldırılar düzenlemişlerdi. Zor duruma düşen Şevardnadze Zviadistlere karşı Rusya'dan askeri yardım istedi. Rus birliklerinin desteğiyle Gürcistan hükümet güçleri Ekim 1993'te Zviadistlere karşı saldırı başlattı. Yaklaşık bir ay içinde Megrelya'nın çoğunda kontrol sağlandı ve Zviadist liderler hapsedildi. Zviadistler bu yenilgiden sonra çok sayıda hükümet karşıtı gösteriler düzenledi ve zaman zaman hükümet güçleriyle çatıştı. Zviadistler 1998 yılında tekrar askeri ayaklanma başlattı. Ancak kısa bir çatışmadan sonra hükümet güçleri durumu kontrol altına aldı. Zviadistler 2003 Gül Devrimi sırasında Şevardnadze'nin iktidardan düşürülmesi için Mihail Saakaşvili ve Zurab Zhvania öncülügündeki muhalif gruplara katıldılar. Zviadistlerin rejim ve hükmet karşıtı isyanları Gürcistan hükümetini çok zor duruma düşürmüştür. Şevardnadze 1993 yılındaki ilk Zviadist isyanında Rusya'dan askeri yardım talep etmek zorunda kalmıştır. Şevardnadze Rus desteği karşılığında Rusya'ya önemli ödünler verdi. Gürcistan bu yardım karşıllğında Rusya'nın öncülüğünde kurulan ve eski Sovyetler Birliği cumhuriyetlerini bir arada tutmayı amaçlayan Bağımsız Devletler Topluluğu'na üye oldu (Mikaberidze, 
2007: 667-669). Abhazya savaşının kaybedilmesi sonrasında başlayan ve rejim güvenliğine yönelen Zviadist isyanı sırasında iç tehdit düzeyindeki artış devleti çökme noktasına getirmiştir. Bu durumla yüzleşen Gürcistan çöküşü engellemek için dış politikada radikal değişikliğe gitmek zorunda kalmıştır.

Gamsahurdiya'nın yönetimi bırakmak zorunda kalmasıyla iktidara gelen Şevardnadze, 2003 yılı sonunda selefi ile aynı kaderi paylaşmıştır. 2 Kasım 2003 tarihinde yapılan genel seçimlerde usulsüzlük yapıldığı gerekçesiyle muhalif ve reformist kanadın önemli temsilcisi olan Mihail Saakaşvili’nin partisi Ulusal Hareket Partisi öncülüğünde şiddetli gösteriler başladı. Diğer kesimlerin destek vermesiyle gösteriler tüm ülkeye yayıldı ve iktidar karşıtlığına dönüştü. Bu gelişmeler karşısında Şevardnadze 23 Kasım 2003 tarihinde devlet başkanlığından istifa etmek zorunda kaldı (Ağacan, 2011: 69). Böylece rejim güvenliğine yönelik tehditler, halk ayaklanmaları yoluyla iktidar değişikliğine yol açmış oldu.

\section{GÜRCISTAN DIŞ POLITTIKASI (1991-2003)}

9 Nisan 1991 yılında bağımsızlığını ilan eden Gürcistan, dış politikada temel olarak uluslararası alanda devlet olarak tanınma, bağımsızlı̆̆ güçlendirme, toprak bütünlügünü sağlama ve iç tehditlerin üstesinden gelmeye odaklanmıştır. Gürcistan'ın ilk devlet başkanı olan Zviad Gamsahurdiya, Rusya'yı bağımsızlık ve toprak bütünlüğü önündeki en büyük engel olarak tanımladı. Gamsahurdiya Rusya tehdidine karşı Batılı ülkelerin desteğini almak için Batıcı söylemler geliştirdi. Ancak Gamsahurdiya yönetimi Gürcistan'ın uluslararası tanınma sorununu çözemedi. Sovyetler Birliği hukuken hala mevcut olduğu için, $\mathrm{ABD}$, Avrupa ve dünya ülkeleri Gürcistan'ı tanımaktan kaçındı. 1992 yılında devlet başkanı olan Şevardnadze döneminde Gürcistan'ın Batılı devletlerce tanınması sorunu çözüldü ve ilişkiler başlatıldı (Sayın ve Modebadze, 2014: 342; Çelikpala, 2012: 67; Ağacan, 2011: 94). Sovyetler Birliği'’nin dağılmasından sonra ortaya çıkan devletler genellikle Rusya'ya karşı daha temkinli bir dış politika izlemeye başladı. Ancak Gürcistan, iç tehditlerin de etkisiyle bağımsızlıktan itibaren daha meydan okuyucu bir politika izledi. Gamsahurdiya dönemi Gürcistan dış politikası da temelde Rusya karşıtı bir çizgide işledi. 
Şevardnadze dönemi Gürcistan dış politikası da iç tehditlerin etkisinde şekillendi. Şevardnadze, Gamsahurdiya döneminden miras alınan toprak bütünlüğü ve merkezi idarenin sağlanması problemleriyle yüzleşti. Bu dönemde Abhazya ve Güney Osetya'da Tiflis'in kontrolü yoktu. Acaristan'ın merkeze bağlılığı azalmıştı. Gürcistan'ın Megrelya bölgesi Zviadist olarak adlandırılan Gamsahurdiya yanlılarının kontrolü altındaydı. Şevardnadze iktidara geldikten sonra ayrılıkçı bölgelerle yaşanan çatışmalar arttı. Güney Osetya ile Gürcistan arasında yaşanan çatışmalara Rusya müdahil oldu ve 24 Haziran 1992 tarihinde Yeltsin ve Şevardnadze arasında çatışmaların durdurulması için bir anlaşma imzalandı. Ayrıca bu anlaşmayla çatışma bölgesine Rus, Gürcü ve Oset askerlerinden oluşan bir barış gücünün yerleştirilmesi kabul edildi. Şevardnadze yönetiminin karşılaştığ diğer toprak bütünlüğü problemi Abhazya ile 14 Ağustos 1992'de başlayan savaştı. Bu savaşı kaybeden Gürcistan bölgeden geri çekilmek zorunda kaldı (Çelikpala, 2012: 70-71).

1993 yılının sonuna kadar Gürcistan-Rusya ilişkileri oldukça gergin bir seyir izledi. Şevardnadze selefi Gamsahurdiya gibi Gürcistan'ın yüzleştiği toprak bütünlüğü sorununun kaynağı olarak Rusya'yı gördü. Şevardnadze yaptığı konuşmalarda etnik sorunların arkasında Rusya'nın olduğunu, Rusya'nın Gürcistan'a düşman olduğunu ifade etti. Şevardnadze bu dönemde, Rusya'nın istekleri olan BDT üyeliği ve Rus askeri üslerin konuşlanmasına yönelik Rusya'nın isteklerini kabul etmedi ve bu isteklerin karşılanmasını bağımsızlığın kaybedilmesi olarak değerlendi. Şevardnadze yönetimi iç savaş boyunca Batı'nın desteğini almaya çalıştı. Bu kapsamda toprak bütünlüğünün korunması ve sorunların çözümü için NATO, AGITT ve BM gibi uluslararası kurumlara başvuruda bulundu. Ancak bu çabalara rağmen Şevardnadze gerekli desteği sağlayamadı (Ağacan, 2011: 85-86). Toprak bütünlüğü sorununun çözümü için Batı'dan aradığı desteği bulamayan Şevardnadze, sorunların çözümü için Rusya'nın çıkarlarının göz önünde bulundurulması gerektiğini düşünmeye başladı. Şevardnadze "Rusya ile işbirliği yapmalıyız, aksi taktirde Gürcistan çökecek ve dağılacaktır" uyarısı yaptı (Ağacan, 2011: 86; Lynch, 2000: 139). Şevardnadze bu politika değişikliğini 1993 y1lı sonlarındaki Abhazya yenilgisi ve yenilgi sonrasında Zviadistlerin hükümete 
karşı isyanı sırasında yaptı. Şevardnadze, Rus askeri birliklerin desteğiyle Zviadist isyanını bastırabilmişti (Mikaberidze, 2007: 668). Şevardnadze bu ortamda Rusya'nın isteklerini kabul etmek zorunda kaldı. Bu kapsamda daha önce üye olmayı reddettiği BDT'ye Ekim 1993'te katılmayı kabul eden Şevardnadze, ayrıca Gürcistan'daki Gudauta, Akhalkalaki, Batum ve Vaziani'deki Rus askeri üslerinin kalmasına ve Türkiye sınırında Rus askerlerinin görev yapmasına onay vermek zorunda kaldı (Sayın ve Modebadze, 2014: 344; Çelikpala, 2012: 72). Şevardnadze bu durumu "BDT üyeliği, Gürcistan'ın bütünlüğünü korumak için son çare” olarak ifade etti (Milliyet, 1993).

Gürcistan'ın dış politikada Rusya'ya yönelik tutum değişikliği ve verdiği tavizler iki ülke ilişkilerinin gelişmesine katkı yaptı. Gürcistan-Rusya yakınlaşması Şubat 1994'te imzalanan Dostluk ve İşbirliği Anlaşması ile zirveye ulaştı. Bu anlaşma ile Gürcistan ve Rusya kapsamlı siyasi, ekonomik ve askeri alanda işbirliğini artırmayı hedefledi. Bu dönem sırasında RusGürcü askeri ilişkileri de hızla gelişti. Rusya ve Gürcistan, Güney Kafkasya'da Rus askeri gücünün artırılması, ortak hava savunma sisteminin kurulması ve sınırların birlikte korunması konularında işbirliği yaptı (Lynch, 2000: 140). Ancak iki ülke ilişkileri 1990'lı yılların ikinci yarısından itibaren özellikle de 1997 yılından sonra giderek bozulmaya başladı. Şevardnadze açıkça Rusya-Gürcistan ilişkilerinde hayal kırıklığının yaşandığını ifade etti. Gürcistan'a göre Rusya toprak bütünlügünün sağlanması konusundaki yükümlülüklerini yerine getirmede başarılı olamadı. Şevardnadze'ye göre stratejik işbirliği hem askeri üslerin konuşlanmasını hem de ülkenin toprak bütünlüğünün restorasyonunu içeriyordu. Şevardnadze'nin Rusya'dan beklentisi Gürcistan ordusunun güçlendirilmesi ve Gürcistan'ın toprak bütünlüğünün restore edilmesine yardımc1 olması yönündeydi. Gürcistan parlamentosu da bu açıklamalara paralel olarak Rusya ile yapılan askeri anlaşmaları onaylamaktan kaçındı. Rusya-Gürcistan ilişkilerindeki gerginlik, 9 Şubat 1998 tarihindeki Şevardnadze'ye yönelik suikast girişimiyle daha da artt1 (Lynch, 2000: 143).

Rusya ilişkileri kötüleşmesine karşın, Gürcistan-ABD ilişkileri 1990'11 yılların ikinci yarısından itibaren ekonomi ve güvenlik alanında gelişmeye 
başlad1. Gürcistan, ABD’nin “Özgürlüklere Destek Kanunu” çerçevesinde 1997'den itibaren ekonomik yardım almaya başladı. ABD, Gürcistan ekonomisine "en çok kayrılan ülke" statüsü vererek ekonomisini destekledi. Güvenlik alanında ABD-Gürcistan ilişkilerinde en önemli adım Mart 1998'de “Askeri ve Güvenlik İşbirliği Anlaşması”nın imzalanmasıdır. Gürcistan bu anlaşma kapsamında ABD’nin "Yabancı Askeri Finansman" ve "Uluslararası Askeri Eğitim" programlarından yararlanmaya başladı. Güvenlik alanında iki ülke ilişkileri 11 Eylül sonrasında daha ileri noktalara taşındı. ABD'nin uluslararası terörizmle mücadele programı kapsamında Gürcistan ordusunun modernizasyonuna yönelik "Gürcistan Eğitim ve Donanım Programı" başlatılmasına karar verildi ve Mayıs 2002'den itibaren uygulanmaya başlandı (Çelikpala, 2012: 75-76). 1990'lı yılların ikinci yarısından itibaren GürcistanNATO ilişkilerinde de önemli sıçrama gerçekleşti. Gürcistan bağımsızlıktan itibaren dış politikada Batı güvenlik kurumlarına katılmayı ve bu şekilde güvenliğini sağlamayı amaçladı. 1990'lı yılların ilk yarısında Batı'dan gerekli desteği alamayan Gürcistan, bu dönemden sonra özellikle NATO ile ilişkileri geliştirme firsatı bulmaya başladı. Kuzey Atlantik İşbirliği Konseyi’ne 1992'de üye olan ve 1994'te "Barış için Ortaklık" programına dâhil edilen Gürcistan, 1997'de kurulan Avrupa-Atlantik Ortaklık Konseyi'nin de kurucuları arasında yer aldı. Bu tarihten sonra NATO-Gürcistan ilişkileri derinleşti. Gürcistan bazı NATO tatbikatlarına ve NATO'nun Kosova ve Afganistan misyonlarına katıldı. Şevardnadze, 2002 NATO Prag Zirvesinde Gürcistan'ın NATO'ya üyelik talebini resmi olarak açıkladı. Gürcistan ayrıca NATO üyeliği için gerekli süreç olan "Bireysel Ortaklık Eylem Planı" programlarına katılma talebinde bulundu. Ardından Aralık 2002'de Gürcistan Ulusal Güvenlik Konseyi tarafından, NATO üyeliğine yönelik “Avro-Atlantik Entegrasyonu Devlet Programı" kabul edildi (Çelikpala, 2012: 76-77; Ağacan, 2011: 99). Batı ülkeleri ve kurumlarıyla ilişkilerin derinleşmesi, Gürcistan'ın temel diş politika ve medeniyet tercihleriyle de uyumluydu.

Gürcistan'in ABD ve NATO ile ilişkilerini derinleştirmesi Rusya ile olan ilişkilerine olumsuz yansıdı. Rusya'ya karşı hareket alanı kazanan Gürcistan, özellikle ülkedeki Rus askeri üslerinin kapatılması ve BDT'den ayrılma konularını gündeme getirdi. Gürcistan bu dönemden sonra Rusya'nın 
yakın çevre politikasını eleştirmeye başladı. Gürcistan, Ukrayna ve Azerbaycan'la birlikte BDT'nin 1997 Kişinev Zirvesi'nde “Rusya'nın hegemonyac1 siyasetini devam ettirmesi durumunda BDT'den ayrılma konusunu gündeme getirebileceklerini" vurgulayan bir bildiri yayınladı. Şubat 1997'de Gürcistan, Ukrayna ve Azerbaycan'la birlikte stratejik işbirliği yapma kararı aldı. Bu karar sonucunda ülkeler, BDT içinde alternatif bir yapılanmaya giderek Moldova'yla birlikte GUAM grubunu oluşturdular. Gürcistan ayrıca Rus askeri üslerinin boşaltılarak ülkedeki Rus askeri varlığının sona erdirilmesi yönünde çabalarını artırdı. Bu çabalar sonuç verdi ve 1999 İstanbul AGITT Zirvesi'nde Rus askeri üslerinin boşaltılması konusunda somut karar alındı. Bu kararla Rusya'nın Gürcistan'daki askeri üslerini 2007 sonuna kadar boşaltması öngörüldü. Rusya bu karar sonrasında Tiflis yakınlarındaki Vaziani'deki üssünü öngörülen tarihte boşalttı (A ğacan, 2011: 100-101; Çelikpala, 2012: 76-77). Gürcistan, Batı'ya yaklaşma ve Rusya'dan uzaklaşma politikasını 2000'li yıllarda da devam ettirdi. Özellikle 2003 y1lı sonundan itibaren iktidar değişikliğinin etkisiyle iki ülke ilişkileri daha da kötüleşmeye başladı.

\section{GÜRCISTAN DIŞ POLITIKASI ANALIZİ}

Birinci bölümde iç tehditlerle dış politika arasında nedensel bir ilişkinin olduğunu varsaymıştık. İkinci ve üçüncü bölümde Gürcistan'ın yüzleştiği iç tehditlerle dış politika davranışları tarihsel akış içerisinde incelendi. $\mathrm{Bu}$ bölümde Gürcistan dış politikasını iç tehdit düzeylerine göre dönemselleştirerek, iç tehditlerin dış politikaya etkisi tartışılacaktır.

\subsection{1-1992 Arası Dönem}

1991-1992 aras1 dönemde Gürcistan, yukarıda ayrıntılı olarak değinildiği gibi, iki tür iç tehditle yüzleşti. Birincisi ve en önemlisi toprak bütünlügüne yönelik tehditlerdi. Bağımsızlıktan hemen sonra Gürcistan'ın içinde özerk birimler olan Abhazya ile Güney Osetya, Gürcistan'dan ayrılma çabalarına girdiler. Gürcistan bu faaliyetlere zaman zaman askeri önlemlerle karşı1ık vermeye çalıştı. Güney Osetya ile yaşanan çatışmalar sonrasında Haziran 1992'de Rusya'nın arabuluculuğunda ateşkes imzalandı. Çatışma bölgesinde tampon yerler oluşturuldu ve bu yerlere Rusya öncülügünde barış 
gücü askerleri yerleştirildi. Gürcistan bir yandan Güney Osetya ile ateşkes anlaşması imzalarken diğer yandan Abhazya sorununu çözmek için askeri yöntemlere başvurdu. İki taraf arasında yaşanan gerginlik, Ağustos 1992'de savaşa dönüştü. Gürcistan'ın bu dönemde yüzleştiği ikinci büyük tehdit rejim güvenliğine yönelen tehditlerdi. Bu tehdidin ortaya çıkmasında Gürcistan'ın ilk devlet başkanı Gamsahurdiya'nın toprak bütünlügüne yönelik tehditlerin üstesinden gelememesi etkili oldu. Bu tehditler iktidar gücü devrinin normal şartlarda gerçekleşmesini engelledi. Gürcistan'ın bağımsızlığa kavuşmasında büyük çaba harcayan ve Mayıs 1991'de yapılan seçimle Gürcistan'ın ilk devlet başkanı olan Gamsahurdiya bir yılı bile doldurmadan halk ayaklanmalarına askeri birliklerin de destek vermesiyle iktidardan ayrılmak zorunda kaldı. Tehdit düzeyi bakımından değerlendirdiğimizde Gürcistan'ın bu dönemde yüzleştiği iç tehditlerin yüksek düzeyde olduğu söylenebilir. Ancak Gürcistan yüksek düzeyli iç tehditleri dengelemede kendisini yeterli görmüş ve zaman zaman askeri önlemeler almıştır. Bu dönemin Gürcistan açısından en önemli özelliği, kendi iç kaynaklarıyla iç tehditlerle mücadele içine girmesidir.

Yüksek düzeyde iç tehditlerle yüzleşen Gürcistan, dış politikasını söz konusu tehditlerle mücadele ekseninde şekillendirmiştir. Gürcistan Rusya'y1 bağımsızlıktan itibaren bağımsızlığına, egemenliğine, toprak bütünlüğüne ve istikrarına tehdit olarak gördü. Bu dönemde Gürcistan'ın dış politikasının temel hedefi Rusya'ya karşı bağımsızlığı güçlendirmek, iç tehditlerden kaynaklanan toprak bütünlüğü sorununu çözmek için Batı ile iyi ilişkiler kurmak, Batı güvenlik kurumlarının ve özellikle ABD’nin desteğini almaya çalışmaktı. Gürcistan, Rusya'yı bağımsızlık ve toprak bütünlüğü önünde engel olarak gördügünden Rusya'nın isteklerine karşı direndi. Ayrıca Rusya'nın bu dönemde genelde yakın çevresine özelde Gürcistan'a yönelik politikası net değildi. Gürcistan bu boşluktan faydalanarak iç tehditlere yönelik daha sert bir politika izledi. Gürcistan ayrıca Rusya'ya ve iç tehditlere karşı ABD'nin desteğini almaya çalıştı. Ancak, "önce Rusya” politikasını izleyen ABD'den beklediği desteği alamadı.

Yine de Gürcistan, bu dönemde hem iç tehditleri hem de dış tehditleri dengeleme politikası izlemiştir. Normal şartlarda güç bakımından Rusya'ya 
göre çok zayıf olan Gürcistan'ın Rusya'nın taleplerine uygun davranması ve onun peşinden gitmesi beklenirdi. Ancak Gürcistan Rusya'yı iç tehditlerin kaynağı olarak gördüğünden ona karşı uyumlu bir politika izlemek veya onu yatıştırmak yerine, meydan okuyucu davranmış ve onun taleplerine direnmiştir. Bu bakımdan 1991-1992 döneminde yüksek düzeyli iç tehditlerin Gürcistan dış politika davranışlarını belirlediğini söyleyebiliriz.

\subsection{3-1996 Arası Dönem}

Gürcistan'ın yüzleştiği iç tehdit düzeyi 1993 yılının son çeyreğinde zirveye çıktı. Bir yıldır sürdürdüğü Abhazya ile olan savaşı kaybeden Gürcistan, rejim güvenliği sorunuyla da yüzleşmek zorunda kaldı. Abhazya savaşının kaybedilmesiyle Zviadistler olarak bilinen ve daha önce darbeyle iktidardan uzaklaştırılan Zviad Gamsahurdiya taraftarları hükümete karşı ayaklanma başlattı ve bazı bölgelerde kontrol sağladı. Bu gelişme Gürcistan'1 çok zor duruma düşürdü ve devleti çökme noktasına kadar getirdi. Gürcistan, 1993 sonlarına doğru içerde yüzleştiği tehditlerin zirveye çıkması nedeniyle dış politikasını değiştirerek Rusya'yı yatıştırma politikası izlemeye başladı. Şevardnadze bu dönemde Rusya ile işbirliği yapılması gerektiği, aksi takdirde Gürcistan'ın çökeceği ve dağılacağı uyarısını yaptı. Gürcistan Rusya'ya tavizler vererek Rusya'nın isteklerini kabul etti. Bu kapsamda Gürcistan BDT'ye üye oldu, ülkesindeki Rus askeri üslerin devamını ve Türkiye sınırında Rus askerinin devriye görevi yapmasını kabul etti. Gürcistan bu tavizleri son çare olarak verdi. Karşılığında da toprak bütünlüğü sorununun çözümü için Rusya'dan güvenceler aldı. Gürcistan bu dönemde Rusya ile ekonomik ve askeri ilişkilerini geliştirdi, Rusya'dan askeri yardımlar almaya başladi.

Bu dönemin en önemli özelliği Gürcistan'ın Rusya'yı dengeleyici ve ona meydan okuyucu davranışları terk ederek, Rusya'nın peşinden gitme politikası benimsemesidir. Bu politika değişikliğinin en önemli nedeni iç tehditleri dengelemedeki başarısızlıktan dolayı iç tehdit düzeyinin devleti çöküşe ve dağılmaya kadar götürecek derecede yükselmesiydi.

\subsection{7-2003 Arası Dönem}


İç istikrarı tehdit eden gelişmeler bakımından bu dönem nispeten durağan geçmiştir. Abhazya ve Güney Osetya ile Rusya öncülüğünde yapılan ateşkes anlaşmaları ve sonrasında oluşturulan barış gücü misyonları nedeniyle taraflar arasında sıcak çatışma yaşanmamıştır. Ancak sorunun nihai çözümüne yönelik bir ilerleme kaydedilememiş, adeta sorunlar dondurulmuştu. Bu dönemde Gürcistan askeri olarak kendisini toparladığından 1998 yılındaki rejime yönelik ikinci Zviadist isyanını kolaylıkla bastırabildi. Ancak Acaristan lideri Abaşidze'nin merkezi yönetim üzerindeki etkisi giderek artmaktaydi.

1996 sonrasında Gürcistan dış politikası daha çok ABD’nin politika değişikliğine göre şekil almaya başladı. Gürcistan $A B D$ ve NATO ile ilişkilerin geliştirilmesine büyük önem verdi. Gürcistan ABD'nin bölgedeki politikalarını ve 11 Eylül sonrasında terörizmle savaş çabalarını büyük bir kararlılıkla destekledi. Hatta ABD'nin 2003 Irak savaşı sırasında Irak'a asker göndererek ABD'nin yanında yer aldı. Gürcistan, başından beri Batı güvenlik kurumlarına entegrasyon politikasına uygun olarak 2002 yılında NATO üyeliği için resmi başvuru yaptı.

Gürcistan, ABD ve NATO ile ilişkilerini geliştirirken Rusya ile olan ilişkileri ise giderek kötüleşmeye ve sertleşmeye başladı. Özellikle 1997 yılından itibaren Rusya'yı bölgede hegemonik davranmakla suçlamaya, politikalarını eleştirmeye başladı. Gürcistan ayrıca BDT içinde kendisiyle aynı çizgide olan ülkelere öncülük ederek ayrı bir oluşuma gidilmesini sağladı. Hatta bu dönemde BDT'den ayrılmayı da gündeme getirdi. Gürcistan ABD'den aldığı destekle egemenliğine tehdit olarak gördüğü ülkesindeki Rus askeri üslerinin kapatılmasını talep etti. Bu talep çerçevesinde 1999 AGiT zirvesinde Rus askeri üslerinin kapatılması konusu takvime bağlandı.

$\mathrm{Bu}$ dönemde iç tehditlerin yatıştırılması ve dış ittifak imkânlarındaki artış Gürcistan'ın iç istikrarını görece güçlendirmiş ve iç tehdit düzeyini düşürmüştür. Bu gelişmeler Gürcistan'ın dış politikada tehdit edici büyük güce karşı meydan okuyucu, dengeleyici davranışlar içine girmesine imkân sağlamıştır. Gürcistan bu dönemde Rusya'nın en büyük rakibi ABD ile askeri ilişkilerini geliştirmiş, Rusya'nın düşman olarak algıladığı NATO ittifakına resmi üyelik başvurusu yapmıştır. 


\section{SONUÇ}

İç tehditler devletlerin dış politika davranışları üzerinde nedensel etkilerde bulunur. İç tehditlerle yüzleşen devletler, bu tehditlerin getirdiği zorunluklardan dolayı sistemik güç dağılımındaki konumlarına uygun olmayan davranışlar gösterebilirler. İç tehdit-dış politika ilişkisi mekanizması mevcut veya potansiyel iç tehditlerle yüzleşen devlet liderlerinin bu tehditleri yatıştırmak, dengelemek veya ortadan kaldırmak için dış destek arayışına girmeleri üzerinden kurulmaktadır. Dolayısıyla devletler iç tehditlere karşı diğer devletlerle veya uluslararası örgütlerle ittifak ve işbirliği yapabilirler.

Meşruiyet eksikliği, yapay devlet inşaları, iç uyum yokluğu gibi belirli yapısal özelliklerden kaynaklanabilen iç tehditler devlet ya da rejim güvenliğini tehlikeye atabilmektedir. Bu tehditler rejim güvenliğine yöneldiği zaman darbeler, şiddetli gösteriler ve halk ayaklanmaları şeklinde görünümler alabilmektedir. Devletin toprak bütünlüğüne yönelik tehditler ise daha çok silahlı çatışmalara ve iç savaşlara varan ayrılıkçı hareketler şeklinde ortaya çıkabilmektedir.

Gürcistan 1991-2003 döneminde hem toprak bütünlüğüne yönelik ayrılıkçı hareketlerle hem de rejim güvenliğine yönelik darbeler ve halk ayaklanmalarıyla yüzleşmiştir. Bu dönemde gerçekleşen iktidar değişimleri normal anayasal kurallara göre değil olağanüstü yöntemlerle gerçekleşmiştir. Söz konusu iç tehditlerin her iki türü, tehdit düzeyine göre, Gürcistan dış politikasını şekillendirmiştir. Tehdit düzeyinin yüksek olduğu ancak Gürcistan'ın iç tehditlerle kendi imkânlarıyla mücadele etmeyi göze aldığı 1991-1992 döneminde Gürcistan hem iç hem de dış tehditleri dengeleme politikası izlemiştir. Bu dönemde Gürcistan tehdit edici büyük komşusu Rusya'nın taleplerine karşı direnmiş, onu yatıştırmayı veya onun peşinden gitmeyi tercih etmemiştir. 1993-1996 döneminin başlarında Gürcistan'ın iç tehditleri dengelemede başarısız olduğunun ortaya çıkmasıyla birlikte iç tehdit düzeyi oldukça yükselmiştir. Devlet olarak çökmenin eşiğine gelen Gürcistan, dış politikada önemli değişim yaparak Rusya ile işbirliği yoluna gitmiştir. $\mathrm{Bu}$ işbirliği karşıllğında Rusya’ya önemli tavizler verilerek Rusya’nın yatıştırılması ve iç tehditlerin dengelenmesi amaçlandı. Rusya ile yapılan işbirliği sonrasında iç istikrar göreceli olarak sağlandı ve sorunlar çözümsüz 
kalsa da iç tehdit düzeyi düşürüldü. İç tehdit düzeyinin düşmesi ve 1990'l1 yılların ikinci yarısından itibaren dış ittifak imkânlarının artması gibi gelişmeler sonrasında Gürcistan, 1996-2003 döneminde, en büyük dış tehdide karşı yeniden meydan okuyucu davranışlar içine girmiştir. $\mathrm{Bu}$ dönemde Gürcistan-Rusya ilişkileri kötüleşirken, Rusya'nın en büyük rakibi ABD ile ilişkileri geliştirmiş ve NATO’ya resmi üyelik başvurusu yapmıştır. Sonuç olarak Gürcistan'ın 1991-2003 döneminde dış politikada yaşadığı yön değişimlerinin temel nedeni, yüzleştiği iç tehditler ve bu tehditlerin düzeylerindeki değişimlerdir. Bu nedenle Gürcistan dış politikası örnek olayının iç tehdit ve dış politika arasında nedensel bir ilişki olduğu varsayımını doğruladığı söylenebilir.

\section{KAYNAKÇA}

Ağacan, K. (2011). Gürcistan: Çok Milletli Yapıda Devlet İnşa Sürecinin Öyküsü. Cavid Veliev ve Araz Aslanlı (der.), Güney Kafkasya: Toprak Bütünlüğ̈̈, Jeopolitik Müdahaleler ve Enerji içinde (s. 57-104). Ankara: Berikan.

Ayoob, M. (1984). Security in the Third World: The Worm About to Turn. International Affairs, 60 (1), No.1, 43-46.

Barnett, M. N. ve Levy, J. S. (1991). Domestic Sources of Alliances and Alignments: The Case of Egypt, 1962-73. International Organization, 45 (3), 369-376.

Çelikpala, M (2012). Başarısız Devlet-Demokratik Model Ülke Sarmalında Gürcistan'ın 20 Yılı. Mustafa Aydın (der.), Kafkasya'da Değişim Dönüşüm (Avrasya Üçlemesi III) içinde (ss. 65-111). Ankara: Nobel.

David, S. R. (1991). Explaining Third World Alignment. World Politics, 43(2), 233-256.

Handel, M. (1990). Weak States in the International System. Londra: Frank Cass.

Harknett, R. J. \& Vandenberg, J. A. (1997). Alingment Theory and Interrelated Therats: Jordan and the Persian Gulf Crisis. Security Studies, 6(3), 112-153.

Jackson, R. (2002). Violent Internal Conflict and the African State: Towards a Framework of Analysis. Journal of Contemporary African Studies, 20(1), 29-52.

Kantarc1, Ş. (2011). Kafkasya'da Etnik Çatışmalar Ekseninde "Güney Osetya" Sorunu, Cavid Veliev ve Araz Aslanlı (der.), Güney Kafkasya: Toprak Bütünlü̈̆̈̈, Jeopolitik Müdahaleler ve Enerji içinde (ss. 229288). Ankara: Berikan. 
Lynch, D. (2000). Russian Peacekeeping Strategies in the CIS: the Cases of Moldova, Georgia and Tajikistan, London: Macmillan.

Mikaberidze, A. (2007). Historical Dictionary of Georgia, Lanham: The Scarecrow Press.

Miller, E. A. \& Toritsyn, A. (2005). Bringing the Leader Back In: Internal Threats and Alignment Theory in the Commonwealth of Independent States. Security Studies, 14(2), 325-363.

Nodia, G. (2005). Georgia: Dimensions of Insecurity. Bruno Coppieters ve Robert Legvold (der.), Statehood and Security: Georgia after the Rose Revolution içinde (ss. 39-82), London: The MIT Press.

Oğan, S. (2011). Kafkasya'da Etnik Çatışmalar Ekseninde Abhazya Sorunu, Cavid Veliev ve Araz Aslanl1 (der.), Güney Kafkasya: Toprak Bütünlüğü, Jeopolitik Müdahaleler ve Enerji, içinde (ss. 193-228), Ankara: Berikan.

Sayın, F. M. \& Modebadze, V. (2014). Georgia's Pro-Western Path: Analysis of The Georgian Foreign Policy in The Post-Soviet Period. AIB Ü Sosyal Bilimler Enstitüsü Dergisi, 14(1), 339-353.

Schweller, R. L. (2004). Unanswered Threats: A Neoclassical Realist Theory of Underbalancing. International Security, 29(2), 170-175.

Schweller, R. L. (1994). Bandwagoning for Profit: Bringing the Revisionist State Back In. International Security, 19 (1), 72-107.

Tiflis'e Rus askeri üssü. (1993, 10 Ekim). Milliyet. s.20.

Walt, S. M. (2009). Alliances in a Unipolar World. World Politics, 61 (1), 86120.

Walt, S. M. (1988). Testing Theories of Alliance Formation: The Case of Southwest Asia. International Organisation, 42(2), s.275-316.

Waltz, K. N. (2010). Uluslararası Politika Teorisi, Osman S. Binatlı (Çev.), Ankara: Phoenix.

Waltz, K. N. (2008). Uluslararası Politikanın Değișen Yapısı. Uluslararası İlişkiler, 5 (17), 3-44.

Wohlforth, W. C. (2004). Revisiting Balance of Power Theory in Central Eurasia. T. V. Paul ve diğ. (ed.), Balance of Power; Theory and Practice in the 21st Century içinde (ss. 214-238), Stanford: Stanford University Press. 